\title{
Clinical time-course and characteristics of islet cell cytoplasmatic antibodies in childhood diabetes
}

\author{
G.J. Bruining ${ }^{1}$, J. Molenaar ${ }^{2}$, C.W.Tuk ${ }^{2}$, J.Lindeman' ${ }^{2}$, H. A. Bruining ${ }^{3}$ and B. Marner ${ }^{4}$ \\ ${ }^{1}$ Department of Pediatrics, Erasmus University and University Hospital Rotterdam/Sophia Children's Hospital, Rotterdam; \\ ${ }^{2}$ Department of Clinical Immunology, Stichting Samenwerking Delftse Ziekenhuizen, Delft; \\ ${ }^{3}$ Department of Surgery, Erasmus University and University Hospital, Rotterdam, The Netherlands and \\ ${ }^{4}$ Hagedorn Research Laboratory, Gentofte, Denmark
}

\begin{abstract}
Summary. Circulating islet cell antibodies (ICA) were present in high frequency $(80 \%)$ early after diagnosis and decreased in the time course of childhood diabetes mellitus. The complement fixing ability of islet cell antibodies (CF-ICA) in the course of the disease appeared to depend on the titre of ICA: the coefficient of correlation between ICA and CF-ICA titres was 0.79 and all ICA's with a titre over 16 were complementfixing. Incubating fresh frozen human pancreatic sections thrice rather than once with the children's sera, increased the detectability of complement fixation by a factor 1.4 in all ICApositive sera. Thus tested, the detection of complement fixation per se did not appear to have a separate pathogenic significance, as the fraction of complement fixing ICA's was almost constant throughout the clinical course. The presence
\end{abstract}

of ICA-IgG subclasses also was dependent on the ICA titre: above a titre of 16 mostly all four subclasses could be detected. Incubating the pancreatic tissue thrice rather than once with ICA-positive sera resulted in enhanced detectability of ICA-IgG ${ }_{1}$. Early in the course of childhood diabetes, including two prediabetic children, most of the IgG subclasses could be detected in ICA, but after a duration of one year $\operatorname{IgG}_{1}$ alone was mainly seen. In two other children, having a family history of insulin-dependency, restriction to the $\mathrm{IgG}_{2}$ subclass was found.

Key words: Juvenile diabetes mellitus, autoantibodies, fluorescent antibody technique, prediabetic state, IgG.
It has been demonstrated that complement-fixing islet cell antibodies (CF-ICA) relate more closely to the clinical onset of childhood diabetes mellitus than non-complement fixing islet cell antibodies (ICA). Importantly, CF-ICA have been found in siblings of diabetic children, up to 4 years before their disease became manifest [1]. There is evidence that CF-ICA encomprise $\beta$ cell cytotoxic antibodies [2], thereby explaining the closer relationship of CF-ICA, rather than ICA, with the actual onset of the disease. Also, CF-ICA tend to disappear more quickly than ICA in the course of the disease [3]. However, the ICA-IgG from sera not fixing complement may react with fewer epitopes in the islet cells, so that the IgG bound would be too far apart to fix sufficient complement components, especially $\mathrm{C}_{3}$. To test this hypothesis, fresh-frozen human pancreatic sections were incubated once or thrice with the patients' sera, to augment the amount of IgG-antibodies reacting with antigens in the islet cells. Subsequently, the ability to fix complement as well as the presence of IgG subclasses in the bound ICA was tested after single or triple serum incubation.
Previously, we compared our methods of detecting ICA between two laboratories [4]. We now report our findings on the occurrence of complement fixation and IgG subclasses during childhood diabetes, including findings in two children who had CF-ICA 28 and 4 months before the clinical onset of diabetes.

\section{Patients and sera}

Sera were obtained from consecutive referrals to the Sophia Children's Hospital of newly diagnosed children (1980-1982) and included follow-up samples (Tables 1, 2 and 4). Figure 1 and Table 3 include samples of recently diagnosed children from other paediatric units (1982). All samples were spun immediately after clotting, frozen at $-20^{\circ} \mathrm{C}$ and assayed within $72 \mathrm{~h}$ for ICA. For all other studies, sera were stored up to 3 years before assay. None of the children had thyroid or adrenal disease.

The 25 newly diagnosed children (Tables 1 and 2) had an average age of 9.2 years (range 3-17 years), the male:female ratio was $1: 1$. On first referral, stable glycosylated haemoglobin levels $\left(\mathrm{HbA}_{1}\right)$ averaged $14 \%$ (range $10 \%-17 \%$ ); 17 children had ketonuria and three had ketoacidosis.

Two patients $(1,2$, Table 4$)$ were CF-ICA positive 28 and 4 months respectively before the diagnosis of clinically overt diabetes, necessi- 
tating the administration of insulin. The data from these patients are omitted from Tables 1, 2, 3 and Figure 1.

Patient 1 (aged 17 years) participated in a study on genetic markers, involving 22 families with two or more children (in total 51) with treated diabetes. These families also had 60 siblings without diabetes. This patient was the only sibling with CF-ICA without any sign of diabetes, a random blood glucose was $5.4 \mathrm{mmol} / \mathrm{l}, \mathrm{HbA}_{1} 6.3 \%$ (normal range $6 \%-8 \%$ ), the disease becoming manifest only 28 months later. None of the other healthy siblings developed diabetes over a 3-year time span.

Patient 2 is a boy, aged 3 years 3 months when insulin was first administered. He is the only son of an insulin-dependent diabetic mother, coming to our attention because of hyperglycaemia ( $\leqq 13.3$ $\mathrm{mmol} / \mathrm{l}$ ) during corticosteroid treatment for severe bouts of asthma. Such bouts lasted 4-7 days and after withdrawing corticosteroids he was normoglycaemic. Three days after the first episode, an oral glucose tolerance test $(1.75 \mathrm{~g}$ glucose $/ \mathrm{kg})$ yielded a peak glucose of $9.7 \mathrm{mmol} / \mathrm{l}$, a peak insulin of $13 \mathrm{mU} / \mathrm{l}$ and an increased C-peptide $>0.2 \mathrm{nmol} / \mathrm{l}$. Glucagon and cortisol were $9-14 \mathrm{ng} / 1$ and $0.27-0.41$ $\mu \mathrm{mol} / \mathrm{l}$, respectively. Five non-diabetic children in this age group had $6.3-7.8 \mathrm{mmol} / 1$ peak-glucose, $10-24 \mathrm{mU} / 1$ peak insulin and $>2$ nmol/1 peak C-peptide during an oral glucose tolerance test. Three months later the oral glucose tolerance test was repeated 3 days after the last corticosteroid dose: by that time peak glucose was $23.8 \mathrm{mmol} / 1$, peak insulin $1 \mathrm{mU} / 1$, peak C-peptide $0.28 \mathrm{nmol} / \mathrm{l}$. This time normoglycaemia did not recur: home-monitored glucose levels varied from 4.4 to $22.2 \mathrm{mmol} / 1$, despite a diet avoiding oligosaccharides. Three weeks later he had another asthmatic episode, necessitating insulin administration since then.

Glucagon, cortisol, insulin and C-peptide were measured by radioimmunoassay, glucose by GOD, glycosylated haemoglobin by microcolumns (Isolab, Akron, Ohio, USA), with the blood drawn in excess saline or buffer prior to assay.

\section{Methods}

\section{Assay procedure for ICA}

For all studies one pancreas specimen was used (designated as 'HP' in the study by Marner et al. [4]). The preparation and storage of the pancreas and the method of assessing ICA in terms of titres (defined as the maximal dilution at which fluorescence can be detected) has been described [4]. Fluorescence readings were made by two observers, discounting very weak $( \pm)$ fluorescence. In cases of doubt, involving $<2 \%$ of all readings, the vote of a third observer was sought. All measurements were carried out as single determinations, unless otherwise indicated.

ICA was determined with fluorescein-isothiocyanate (FITC)-labelled rabbit anti-human IgG, IgA and IgM sera specific for the heavy chain, purchased from the Central Laboratory of the Blood transfusion Service, Amsterdam, the Netherlands (anti-IgG, batch number: KH-16-105-F01, anti-IgA, batch number: KH-14-17-F01, anti-IgM (batch number: KH-15-21-F01)). A Leitz Orthoplan microscope (Wetzlar, FRG) with epi-illumination (100 Watt lamp) and dichroic mirror RKP 510 with filter LP 515 (Wetzlar, FRG) were used.

In two out of 46 samples IgG-rheumatoid factors were found [5]. Those samples were excluded from the study.

\section{Complement-fixing ICA}

Since complement binding to IgG is dependent on the close proximity of IgG molecules, the occurrence of CF-ICA was tested under two different conditions, i.e. pancreas sections were incubated once (complement-fixing-titre) and thrice (complement-fixing-property) with preheated $\left(30 \mathrm{~min}, 56^{\circ} \mathrm{C}\right)$ patient sera $(50 \mathrm{\mu l})$ for $30 \mathrm{~min}$. The sections were washed with phosphate buffered saline (PBS, pH 7.2) and incubated with human serum as a complement source (fresh serum, blood group $\mathrm{AB}$, stored $-80^{\circ} \mathrm{C}$, diluted $1: 5$ ). After another washing proce-
Table 1. Prevalence of islet cell cytoplasmatic antibodies (ICA) in the sera of diabetic children in relation to the duration of diabetes

\begin{tabular}{|c|c|c|c|c|}
\hline \multirow{2}{*}{$\begin{array}{l}\text { Months } \\
\text { after } \\
\text { diagnosis }\end{array}$} & \multirow{2}{*}{$\begin{array}{l}\text { Number } \\
\text { of } \\
\text { patients } \\
\text { studied }\end{array}$} & \multirow{2}{*}{$\begin{array}{l}\text { ICA- } \\
\text { positive }\end{array}$} & \multicolumn{2}{|c|}{ ICA-fixing complement } \\
\hline & & & $\begin{array}{l}\text { After one } \\
\text { serum } \\
\text { incubation }\end{array}$ & $\begin{array}{l}\text { After three } \\
\text { serum } \\
\text { incubations }\end{array}$ \\
\hline $0-3$ & 25 & $20 / 25 \quad(80 \%)$ & $12 / 20(60 \%)$ & $15 / 20(75 \%)$ \\
\hline $4-12$ & 13 & $8 / 13 \quad(62 \%)$ & $1 / 8 \quad(13 \%)$ & $4 / 8 \quad(50 \%)$ \\
\hline $13-24$ & 12 & $2 / 12 \quad(17 \%)$ & $1 / 2 \quad(50 \%)$ & $1 / 2 \quad(50 \%)$ \\
\hline $25-48$ & 19 & $7 / 19 \quad(37 \%)$ & $3 / 7 \quad(43 \%)$ & $4 / 7 \quad(57 \%)$ \\
\hline$\geqslant 48$ & 37 & $4 / 37(11 \%)$ & $2 / 4 \quad(50 \%)$ & $3 / 4 \quad(75 \%)$ \\
\hline Total & 106 & $41 / 106$ & $19 / 41$ & $27 / 41$ \\
\hline $\begin{array}{l}\text { Healthy } \\
\text { controls }\end{array}$ & 100 & $1 / 100(1 \%)$ & $0 / 1 \quad(0 \%)$ & $0 / 0 \quad(0 \%)$ \\
\hline
\end{tabular}

dure the presence of $\mathrm{C}_{3}$ was demonstrated by incubation with FITCconjugated rabbit anti-human $\mathrm{C}_{3 \mathrm{c}}(1: 80$ dilution, Dakopatts $\mathrm{A} / \mathrm{S}$, Copenhagen). Fluorescence was evaluated as described above.

The conjugate did not react with human IgG, nor could fluorescence be demonstrated under the above conditions, if ICA-positive samples (titres 8-64) were incubated thrice with tissue in the absence of $\mathrm{C}_{3}$.

\section{ICA-IgG subclasses detection}

For the determination of IgG subclasses in ICA, specific rabbit antihuman IgG subclass sera were used. The principle of the preparation of these sera has been described [6]: they were made specific in agglutination and subsequently in indirect immunofluorescence by adsorption with a panel of relevant isolated IgG-paraproteins and tested against IgG subclass-paraproteins bound to erythrocytes by tannin. When applied to bone marrow smears obtained from multiple myeloma patients, these subclass antisera appeared suitable for use by indirect immunofluorescence. The sensitivity and specificity of these anti-sera (anti-IgG ${ }_{1}$, batch number: KH161-02-A $\mathrm{A}_{1}$; anti-IgG $\mathrm{Ig}_{2}, \mathrm{KH}$ 162-19- $\mathrm{A}_{6}$; anti-IgG ${ }_{3}, \mathrm{KH}$ 163-01- $\mathrm{A}_{1}$; anti-IgG $\mathrm{IgH}_{4}$ KH4-05- $\mathrm{A}_{3}$, obtained from the Central Laboratory of the Blood Transfusion Service, Amsterdam) was found adequate in immunofluorescence, as well as in an enzyme-linked immunosorbent assay (Elisa) in two other studies $[7,8]$.

To demonstrate the occurrence of a particular IgG-subclass, ICApositive sera were incubated once or thrice with pancreatic tissue and subsequently tested for the subclasses. Anti-IgG subclass sera were used at 1:20 dilution (excepting anti-IgG $2,1: 40$ ) and were applied in a double layer method in conjunction with FITC-labelled swine antirabbit Ig (1:80 dilution, F 205, Dakopatts, Copenhagen). The latter did not cross-react with human $\operatorname{IgG}$, as demonstrated by the absence of fluorescence when tested directly on bone marrow cells of 10 multiple myeloma patients or when tested on pancreas sections bound with ICA. Finally, conjugate extensively adsorbed with human IgG gave no change in $\mathrm{IgG}$ subclass detection.

\section{Results}

Table 1 indicates the prevalence of ICA and CF-ICA during childhood diabetes. Each sample assayed came from a different child. At the onset of disease the prevalence of ICA was $80 \%$, but after a duration of 4 years or more, only $11 \%$ of the children had circulating ICA. All positive sera contained ICA of the IgG class. In addition, two sera contained ICA-IgA. ICA-IgM were not found. 


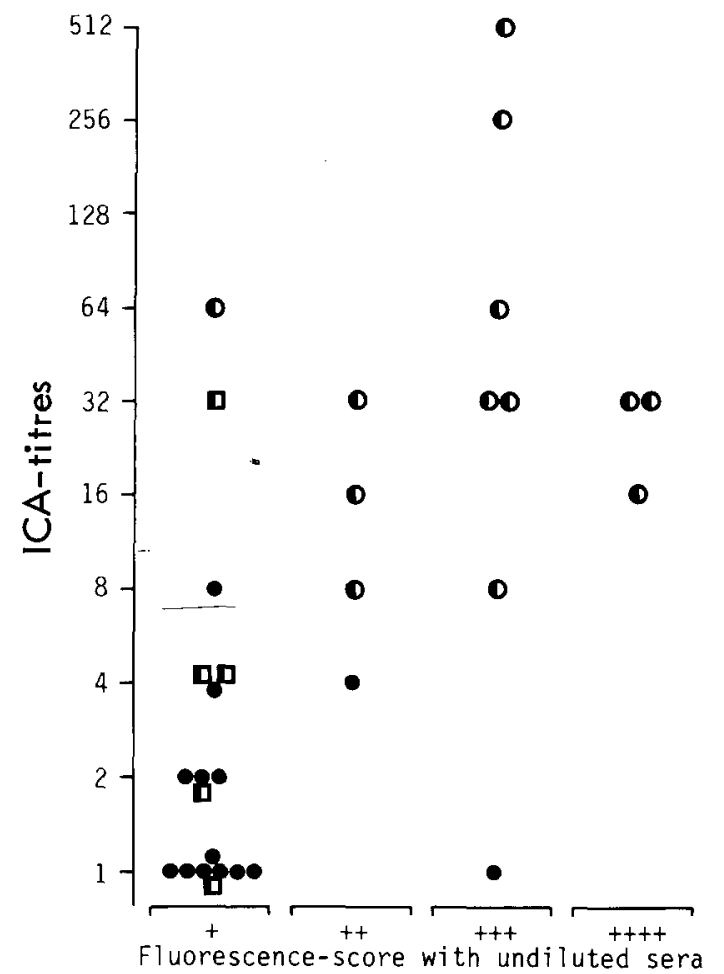

Fig. 1. The relationship between fluorescence-score and islet cell antibody (ICA) titre. ICA that did not fix complement after one or three incubations; 0 ICA that fixed complement on single incubation; D ICA that fixed complement only after triple incubation

Table 2. Follow up of islet cell antibody (ICA) and complement-fixing islet cell antibody (CF-ICA) titres $0-12$ months after diagnosis

\begin{tabular}{lllll}
\hline $\begin{array}{l}\text { Patient } \\
\text { no. }^{2}\end{array}$ & \multicolumn{4}{l}{ ICA/CF-ICA ${ }^{\mathrm{b}}$ titres } \\
\cline { 2 - 5 } & 0 months & $0-5$ months & $5-10$ months & $8-12$ months \\
\hline 1 & $32 / 2(0)$ & $32 / 4(3)$ & $64 / 16(7)$ & \\
2 & $2 / 0(0)$ & $2 / 0(2)$ & & $2 / 0(11)$ \\
3 & $8 / 0(0)$ & $0 / 0(2)$ & $0 / 0(5)$ & $0 / 0(8)$ \\
4 & $64 / 2(0)$ & $64 / 4(2)$ & $16 / 1(5)$ & $16 / 1(9)$ \\
5 & $8 / 1(0)$ & $8 / 1(2)$ & $16 / 4(7)$ & \\
6 & $32 / 2(0)$ & $16 / 2(3)$ & $8 / 1(10)$ & $8 / 0(12)$ \\
7 & & $16 / 4(5)$ & $16 / 8(8)$ & $8 / 4(11)$ \\
8 & $16 / 4(0)$ & $16 / 2(3)$ & $8 / 2(6)$ & \\
\hline
\end{tabular}

${ }^{a}$ Eight patients [randomly selected from the 25 (0-3 months) of Table 1]; ${ }^{\mathrm{b}} \mathrm{CF}$-ICA titres obtained after single incubation of the sera follow the corresponding ICA-IgG titre and the exact number of months after diagnosis is shown in parentheses

If the sera were incubated once with pancreatic tissue, complement fixation was found in $46 \%(19 / 41)$ of the samples (Table 1), but triple incubation of the same sera increased the percentage fixing complement by a factor 1.4 (to 27/41). Of 100 healthy adult blood donors one sample was weakly positive for ICA and none for CF-ICA.

A significant linear correlation could be demonstrated between the fluorescence intensity score observed with undiluted sera and the ICA titre of 32 sam- ples tested ( $p<0.05$, Fig. 1). Thirteen samples with a titre $\geqq 8$ were CF-ICA positive after single incubation. Only two of the 20 samples with an ICA titre $\leqq 8$ were CF-ICA positive on single incubation, the standard procedure. Triple incubation resulted in four additional CF-ICA positives among these 20 samples with ICA titres $\leqq 8$. None of the sera with CF-ICA activity on single incubation lost this capacity by triple incubation.

Of ten samples that lost their complement fixation by dilution $1: 3$, the complement fixing property reappeared in nine of them after triple incubation. In the sera of 25 healthy adult blood donors no complement fixation could be detected after triple incubation with the pancreatic tissue.

The sequential titres of Table 2 show a gradual decrease of ICA as well as CF-ICA titres during the first year of diabetes treatment. A strong correlation was found between ICA and CF-ICA titres obtained after single incubation (Spearman's rank correlation gave a rho of $0.79, p<0.0001)$. The CF-ICA titres were 16-2-fold lower than those of ICA-IgG.

Table 3 shows the relationship between ICA titres and IgG subclasses detection. The first samples of 44 recently diagnosed diabetic children ( $0-12$ months after diagnosis) were tested for ICA-IgG subclasses after single or triple incubation of the sera with the tissue.

Firstly, we considered samples that fixed complement after single incubation and in which ICA-IgG subclasses were determined by single incubation. In this category samples with an ICA-IgG titre $>16$ had most IgG subclasses detectable. Secondly, of the 27 samples with ICA-IgG titres $\leqq 8$, the number of IgG subclasses detected exceeded two in only three samples, all of which fixed complement on single incubation.

Finally, the 17 samples that either did not fix complement at all or only after triple incubation all had an ICA titre of $\leqq 16$ and in six of these sera no IgG subclass was detectable, regardless of the incubation procedure.

The above findings raise the question whether the detectability of specific IgG subclasses may be enhanced or suppressed by single or triple serum incubation. IgG subclasses were detected in 37 of the 44 ICApositive samples of Table 3 , after single or triple incubation. Of those 37 sera, 34 contained $\operatorname{IgG}_{1}, 17$ $\mathrm{IgG}_{2}, 18 \mathrm{IgG}_{3}, 10 \mathrm{IgG}_{4}$.

ICA-IgG ${ }_{1}$ was detected in $9 / 27$ sera with ICA-Ig titre $\leqq 8$, while triple incubation resulted in the detection of $20 / 27$ ICA-IgG $_{1}$. In one sample only of this category was ICA-IgG 1 lost by triple incubation. The chi square test for paired observations gave $p<0.05$ for this comparison. Thus, $\operatorname{IgG}_{1}$ detectability was enhanced by triple incubation in CF-ICA. In CF-ICA negative sam-

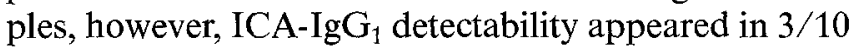
samples by triple incubation and disappeared in $2 / 10$.

With the other IgG subclasses no significant suppression or enhancement of detectability was found by single or triple incubation. 
Table 3. The distribution of IgG subclasses $(1,2,3,4)$ in relation to ICA-IgG titre and complement fixation in sera of newly diagnosed diabetic children

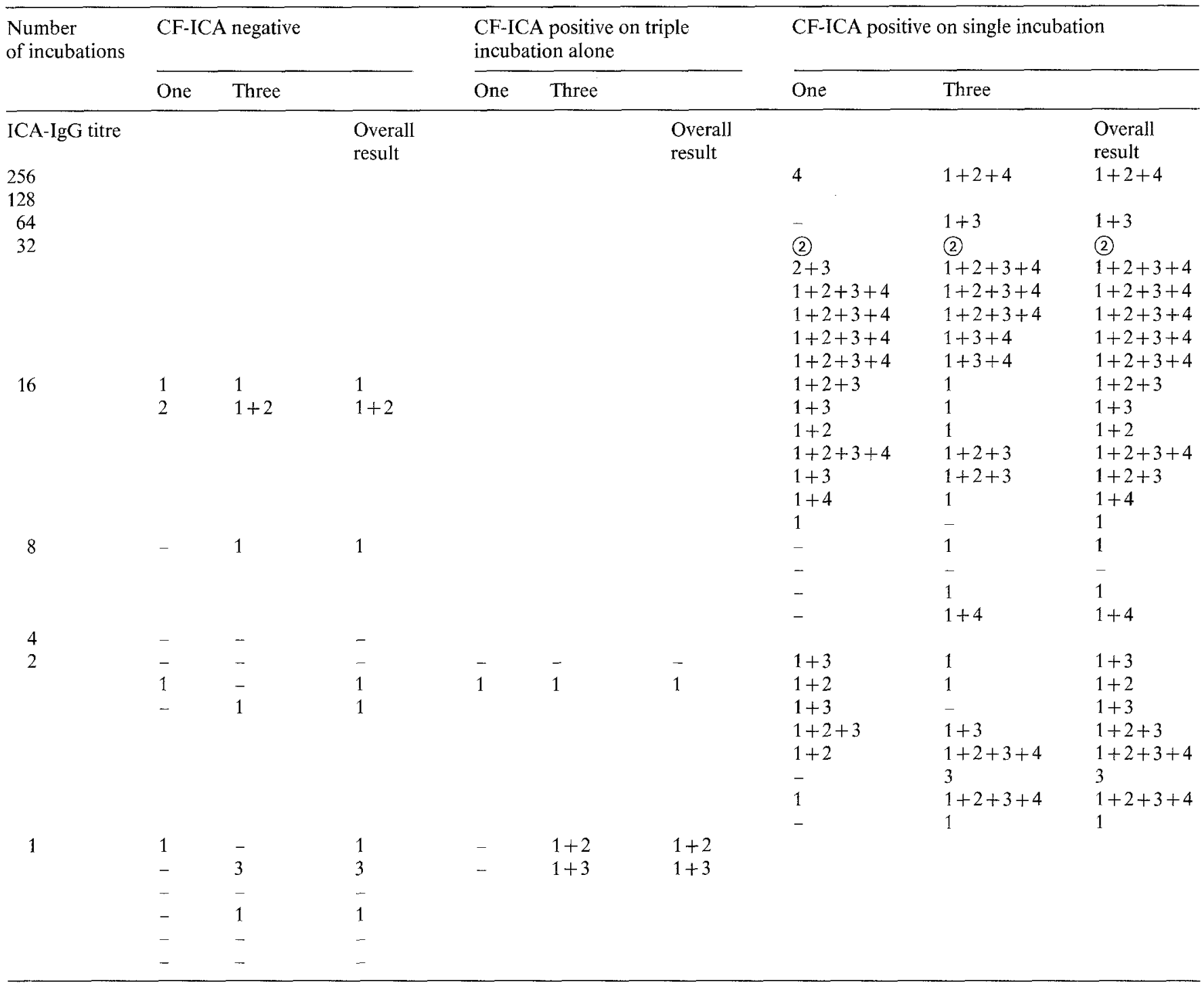

Seven patients were followed up from before their diagnosis up to 20 months thereafter (Table 4). Despite variability in the detection of $\operatorname{IgG}$ subclasses caused by single or triple incubations, consistency of $\mathrm{IgG}$ subclasses was found in parts of the clinical course. Changes in subclasses were seen in patients 1,2 and 5 where a 16-fold decrease in ICA-IgG titre was found.

In all patients, excepting patient $6, \mathrm{IgG}_{1}$ was the predominant ICA-IgG subclass detected in the time course of their disease. This result is in agreement with the quantitative distribution of $\mathrm{IgG}$ subclasses found in the sera of 50 normal children, aged 8-12 years, using the same antisera $\left(\operatorname{IgG}_{1}: \operatorname{IgG}_{2}: \operatorname{IgG}_{3}: \operatorname{IgG}_{4}=70: 20: 8: 4\right)$. Ten randomly selected children with treated diabetes had a similar IgG subclass distribution to that found in the sera of normal children (data not shown).

Patient 6 (encircled in Table 4) with ICA- $\mathrm{IgG}_{2}$ alone and another patient (encircled in Table 3 ) having ICA-
$\mathrm{IgG}_{2}$ only on single as well as triple serum incubation, had family histories of insulin-dependency. The maternal grandfather of the first patient was insulin-dependent at age 27 years and his maternal uncle developed diabetes at age 10 years. The other patient had two maternal great-uncles with insulin-dependency as of ages 36 and 49 years. The sera of these two patients, however, contained normal quantities of $\operatorname{IgG}$ subclasses.

\section{Discussion}

The complement fixing nature of ICA may be particularly relevant for the pathogenesis of childhood diabetes as this variety of ICA has been detected in children before the disease becomes clinically manifest [1]. This association is confirmed by two more cases in the present study. In clinically overt childhood diabetes, no 
Table 4. Follow up of IgG subclasses in complement-fixing islet cell antibodies (CF-ICA) before and after diagnosis

\begin{tabular}{|c|c|c|c|c|}
\hline Patients $^{\mathrm{a}}$ & $\begin{array}{l}\text { Months after }(+) \\
\text { or before }(-) \\
\text { diagnosis }\end{array}$ & $\begin{array}{l}\text { IgG subclasses } \\
\text { detection }^{\mathrm{b}}\end{array}$ & $\begin{array}{l}\text { ICA-IgG } \\
\text { titre }^{\mathrm{c}}\end{array}$ & $\begin{array}{l}\text { CF-ICA } \\
\text { titre }^{c}\end{array}$ \\
\hline 1 & $\begin{array}{c}-28 \\
1\end{array}$ & $\begin{array}{l}1+2+3+4 \\
1\end{array}$ & $\begin{array}{r}64 \\
4\end{array}$ & $\begin{array}{r}16 \\
1\end{array}$ \\
\hline 2 & $\begin{array}{l}-4 \\
-1 \\
+2 \\
+4\end{array}$ & $\begin{array}{l}1+2+4 \\
1+2+4 \\
1+2+4 \\
\text { nd }\end{array}$ & $\begin{array}{r}32 \\
16 \\
8 \\
2\end{array}$ & $\begin{array}{c}1 \\
1 \\
1 \\
(1)^{\mathrm{d}}\end{array}$ \\
\hline 3 & $\begin{array}{r}1 \\
6 \\
17\end{array}$ & $\begin{array}{l}1 \\
1 \\
1\end{array}$ & $\begin{array}{l}8 \\
8 \\
4\end{array}$ & $\begin{array}{l}1 \\
4 \\
2\end{array}$ \\
\hline 4 & $\begin{array}{r}0 \\
7 \\
10 \\
16\end{array}$ & $\begin{array}{l}1 \\
1 \\
1 \\
1\end{array}$ & $\begin{array}{r}32 \\
8 \\
4 \\
4\end{array}$ & $\begin{array}{l}2 \\
1 \\
1 \\
1\end{array}$ \\
\hline 5 & $\begin{array}{r}5 \\
10 \\
19\end{array}$ & $\begin{array}{l}1+2+4 \\
1+2+4 \\
1\end{array}$ & $\begin{array}{r}16 \\
8 \\
1\end{array}$ & $\begin{array}{l}4 \\
2 \\
0\end{array}$ \\
\hline 6 & $\begin{array}{r}7 \\
14\end{array}$ & (2) & $\begin{array}{r}16 \\
4\end{array}$ & $\begin{array}{l}8 \\
2\end{array}$ \\
\hline 7 & $\begin{array}{r}3 \\
12 \\
19\end{array}$ & $\begin{array}{l}1 \\
1 \\
1\end{array}$ & $\begin{array}{l}8 \\
4 \\
4\end{array}$ & $\begin{array}{l}1 \\
1 \\
1\end{array}$ \\
\hline
\end{tabular}

nd $=$ not detectable

${ }^{a}$ Five patients (3-7) were randomly selected from the 25 of Table 1 and children 1,2 were those in whom ICA was measured before the disease became clinically manifest; ${ }^{b}$ IgG subclasses are given as the overall result of their detection by single and triple incubation; ${ }^{c}$ titres are those obtained after single incubation of the sera with the tissue. All measurements were done in triplicate and the average titre reported. The reproducibility was always within one titre difference; ${ }^{d}$ after triple incubation only

complement fixation was found if the ICA-IgG titre was 4 or lower, whereas the correlation between ICAIgG and CF-ICA titres was high, suggesting a limited sensitivity of our system for the detection of CF-ICA titres.

The fixing of complement depends on the proximity of Ig-antibodies bound to the islet cells of the pancreatic sections. Triple incubation resulted in the detection of 1.4 times as many complement fixing ICA as single incubation (Table 1), primarily because samples with ICA-IgG titres of 4 or lower appeared to fix complement by this procedure (Fig.1). If CF-ICA-positive samples were diluted until the complement fixing detectability disappeared and were subsequently incubated thrice at that dilution, the complement fixing property reappeared. This finding raises the question whether the complement fixing nature of ICA has any significance other than that it is more likely to be seen in samples with higher ICA-IgG titres. As in other studies, ICA decreased with the duration of the diabetes. However, our fraction of ICA's fixing complement remained $50 \%-75 \%$ (Table 1). Therefore, we do not feel the detection of complement-fixation per se has a separate significance.
Dean et al. [9] recently investigated ICA-IgG subclasses and found $50 \%$ of the ICA-positive sera showed a restricted response, with $12 \%$ reacting only with the $\mathrm{IgG}_{2}$ subclass. We too found an uneven distribution of IgG subclasses, however some apparent restrictions were clearly dependent on the ICA-IgG titre on which in turn the CF-ICA titre depended. Dean et al. found the restrictions to be independent of CF-ICA titres, although their reported $\mathrm{CF}$-ICA titres were much higher than those in the present study. We used triple incubation of the pancreatic sections to enhance the detectability of complement fixation and if samples demonstrating all four ICA-IgG subclasses were diluted, $\operatorname{IgG}_{1}$ was the last subclass to disappear. Conversely, triple incubation significantly enhanced the detectability of $\mathrm{IgG}_{1}$. In addition, the $\operatorname{IgG}_{1}$ subclass appeared predominant in 13 ICA-positive sera not fixing complement, which suggests again that the $\operatorname{IgG}_{1}$ subclass was more abundant in ICA, as in whole serum. The absence of detection of any IgG-subclass in seven sera of lower ICAIgG titre could be due to the limited number of epitopes present in ICA which are specific for the relevant subclasses. The finding that ICA with lower titres did not fix complement may be due to the low density of ICA bound from those sera. The discrepancies indicated may be resolved with the availability of monoclonal IgG subclass antisera and sensitive enzyme-labelled or radiolabelled assays [10], now that two human ICAreactive islet cell protein fractions have been separated [11].

In conclusion, indirect immunofluorescence carried out on one single fresh-frozen human pancreas, with a previously established specificity and sensitivity for the detection of ICA [4], yielded variable results for the detection of complement fixation and IgG subclasses, depending on ICA-IgG titres and incubation procedures. The present data suggest the occurrence of a non-restricted $\operatorname{IgG}$ subclass response early in the course of childhood diabetes. However, $\mathrm{IgG}_{2}$ subclass restriction in ICA was seen in two children having a family history of insulin-dependency.

Acknowledgements. We thank Professor Dr. H.J. Degenhart for statistical advice and Professor Dr. R. Benner, Department of Immunology, for his critical review of this manuscript. The secretarial assistance of Ms. E. Berkouwer and Ms. A.de Reus is gratefully acknowledged. The work was supported in part by the Sophia Foundation for Medical Research.

\section{References}

1. Gorsuch AN, Spencer KM, Lister J, Wolf E, Bottazzo GF, Cudworth $\mathrm{AG} \dagger$ (1982) Can future Type 1 diabetes be predicted? A study of families of affected children. Diabetes 31: 862-867

2. Van de Winkel M, Smets G, Gepts W, Pipeleers D (1982) Islet cell surface antibodies from insulin-dependent diabetics bind specifically to pancreatic B cells. J Clin Invest 70:41-49

3. Lernmark A, Hägglöf B, Freedman ZR, Irvine WJ, Ludvigsson $J$, Holmgren $G$ (1981) A prospective analysis of antibodies reactive 
with pancreatic islet cells in insulin-dependent diabetic children. Diabetologia $20: 471-474$

4. Marner B, Lernmark A, Nerup J, Molenaar JL, Tuk CW, Bruining GJ (1983) Analysis of islet cell antibodies on sections of human pancreas. Diabetologia 25:93-96

5. Estes D, Atra E, Peltier A (1973) An immunofluorescent method for the detection of antigamma-globulin antibodies. Arthritis Rheum 16:1-9

6. Van der Giessen M, Freyee W, Rossouw E, van Loghem E (1973) Qualitative and quantitative studies on $\mathrm{IgG}_{2}$ globulins in individual human sera with an antiserum capable of differentiating between $\mathrm{Gm}(\mathrm{n}+)$ and $\mathrm{Gm}(\mathrm{n}-)$ proteins. Clin Exp Immunol 14: $127-132$

7. Von dem Borne AEGK, Helmerhorst FM, van Leeuwen EF, Pegels HG, van Riesz E, Engelfriet CP (1980) Autoimmune thrombocytopenia: detection of platelet antibodies with the suspension immunofluorescence test. Br J Haematol 45: 319-327

8. Horai S, Class FHJ, van Rood JJ (1981) Detection of platelet antibodies by enzyme linked immunosorbent assay (Elisa). Comparative studies with the indirect immunofluorescence assay. Immunol Lett 3: 155-158
9. Dean BM, Bottazzo GF, Cudworth AG (1983) IgG-subclass distribution in organ specific autoantibodies. The relationship to complement-fixing ability. Clin Exp Immunol 52: 61-66

10. Huen AHJ, Haneda M, Freedman Z, Lernmark A, Rubenstein AH (1983) Quantitative determination of islet cell surface antibodies using ${ }^{125}$ I-protein A. Diabetes 32: 460-465

11. Baekesshov S, Nielsen JH, Marner B, Bilde T, Ludvigsson J, Lernmark A (1982) Autoantibodies in newly diagnosed diabetic children immunoprecipitate human pancreatic islet cell proteins. Nature 298: 167-169

Received: 21 March 1983

and in revised form: 12 October 1983

Dr. G.J. Bruining,

Sophia Children's Hospital

160 Gordelweg

NL-3038 GE Rotterdam

The Netherlands 